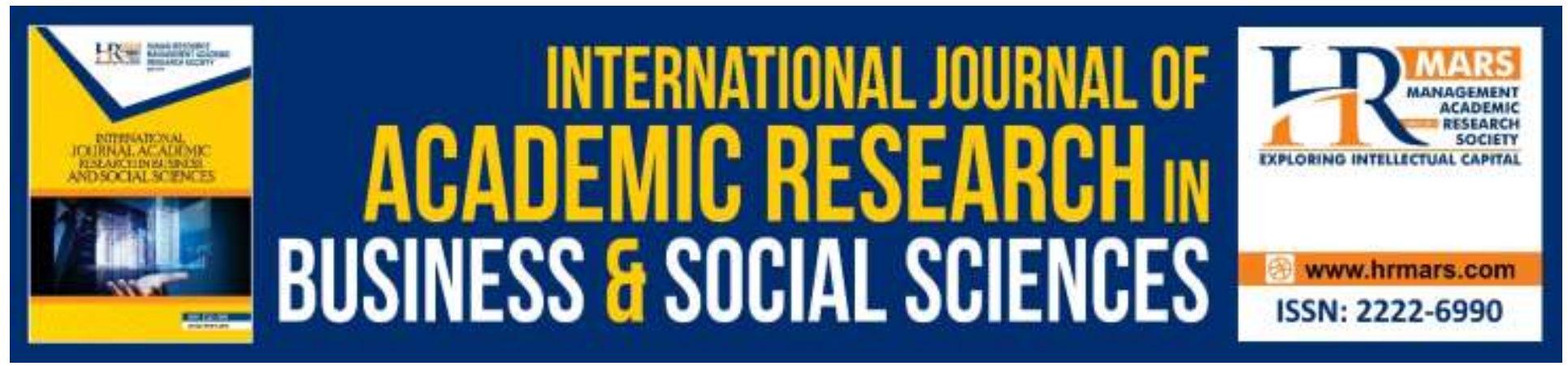

\title{
Determinants of Socially Responsible Decisions among Managers: A Preliminary Study
}

\section{Siti Noormi Alias, Ee Min Jun \& Zoharah Omar}

To Link this Article: http://dx.doi.org/10.6007/IJARBSS/v9-i11/6708

DOI: 10.6007/IJARBSS/v9-i11/6708

Received: 11 October 2019, Revised: 30 October 2019, Accepted: 06 November 2019

Published Online: 30 November 2019

In-Text Citation: (Alias, Jun, \& Omar, 2019)

To Cite this Article: Alias, S. N., Jun, E. M., \& Omar, Z. (2019). Determinants of Socially Responsible Decisions among Managers: A Preliminary Study. International Journal of Academic Research in Business and Social Sciences, 9(11), 1402-1428.

\section{Copyright: (c) 2019 The Author(s)}

Published by Human Resource Management Academic Research Society (www.hrmars.com)

This article is published under the Creative Commons Attribution (CC BY 4.0) license. Anyone may reproduce, distribute, translate and create derivative works of this article (for both commercial and non-commercial purposes), subject to full attribution to the original publication and authors. The full terms of this license may be seen at: http://creativecommons.org/licences/by/4.0/legalcode

Vol. 9, No. 11, 2019, Pg. 1402 - 1428

Full Terms \& Conditions of access and use can be found at http://hrmars.com/index.php/pages/detail/publication-ethics 


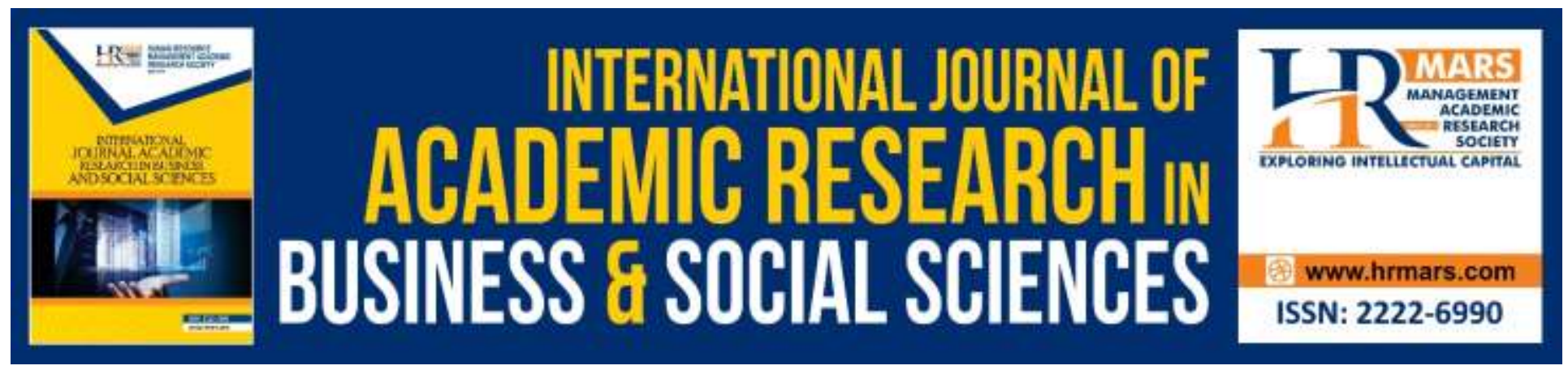

\title{
Determinants of Socially Responsible Decisions among Managers: A Preliminary Study
}

\author{
Siti Noormi Alias, Ee Min Jun \& Zoharah Omar \\ Department of Professional Development and Continuing Education, Faculty of Educational \\ Studies, Universiti Putra Malaysia (UPM), Malaysia
}

\begin{abstract}
Despite of the arising number of studies on Corporate Social Responsibility (CSR), nevertheless, less research has explored individual factors influencing socially responsible decision among managers in Malaysia. Therefore, this preliminary study seeks to find the relationship between individual factors and socially responsible behaviour among managers. A total of 73 respondents were selected though stratified random sampling method. The findings of the study revealed that all individual factors (empathic concern, internal locus of control and cognitive moral development) are positively correlated with socially responsible behavior and there are moderate and positive relationship between them. Meanwhile, among these individual factors, cognitive moral development was the most influential factors affecting socially responsible behavior among managers in Klang Valley. This study provides a support for the direction to Human Resource Development and Organizational Development practice based on Malaysian context. This study also supports the Theory of Planned Behaviour and Stakeholder Theory on socially responsible behavior among managers in Klang Valley.

Keywords: Socially Responsible Decision, Empathic Concern, Locus of Control, Cognitive Moral Development
\end{abstract}

\section{Introduction}

The interest in corporate social responsibility (CSR) getting amplified among business organizations because it has been proclaimed as a key tool to support the companies to meet societal and environmental pressures as well as for business competitiveness (Ramesh, Saha, Goswami, Sekar, \& Dahiya, 2019; Boulouta \& Pitelis, 2014; Carroll \& Shabana, 2010). It is believed that CSR activities are able to address consumers' social concerns, develop and maintain a positive corporate image, and therefore, create added value to the business operations. According to Walton (1967), CSR in an organization arises as a set of actions taken by managers solely through corporate decisions. Establishment of any CSR activities in an organization must be 
approved and supported by top management with decision making power (Cullinan, Bline, Farrar, \& Lowe, 2008; Wen \& Song, 2017; Jiang, Zalan, Tse, \& Shen, 2018). Individuals with decision making power in an organization may include board of directors (Zhang \& Greve, 2019) and those who have both superiors and subordinates (Xu, Joyce, Aili, \& Yaping, 2010). Additionally, each decision made are linked with individual factors (Ford \& Richardson, 1994; Pollanen, AbdelMaksoud, Elbanna, \& Mahama, 2017) such as locus of control, emphatic concern, and cognitive moral development. Ellen et al. (1991) emphasized that individual factors will make difference in making decision to contribute.

In Malaysia, corporate sectors are encouraging to involve in CSR initiatives by giving back to the society. It is clearly stated in the 11th Malaysia Plan that integration and collaboration between all stakeholders (i.e., public, private sectors and non-governmental organizations) are required "to enable all Malaysian, regardless of where they live or how much they earn to achieve a comfortable standard of living and quality of life" (Malaysia Prime Minister's Department, 2015). In accordance, numerous CSR activities done by them involving three key areas, including education (e.g., providing scholarships and sponsorships), communities (e.g., charity dinner, monetary contribution to orphanage and charity run), and employees (e.g., giving several relevant training programs like healthcare awareness, and water safety program) (Ismail, Amat Johar, Rasdi, \& Alias, 2014; Shbail, 2018. For instance, Khazanah Nasional Berhad established Yayasan Khazanah Foundation as a part of its CSR initiatives to ensure financial support among students with exceptional intelligence and accomplishment to attend premier universities in Malaysia or around the world through full funded scholarships. Another initiative empowered by corporate Malaysia, known as PINTAR Foundation established to complement existing ongoing efforts by the government to provide equitable access to quality education for all (PINTAR Foundation, 2014). Corporate members actively contributing to the foundation include CIMB Foundation, Danajamin, Malaysia Airlines, Tenaga Nasional Berhad, ValuCAP, and Yayasan Tan Sri SM Nasimuddin. The emphasis of the program are towards a) motivational and team building program (leadership), b) educational support program, c) capability and capacity building, and d) reducing vulnerabilities and social issues. Since its establishment in 2014, 513 schools were adopted by the corporate members.

Due to increasing number of CSR activities conducted, scholars and practitioners are more interested in examining the effect of CSR practices toward organizational financial performance (e.g., Cho, Chung, \& Young, 2019; Woon, Sambasivan, Jo, \& Siong, 2019), types of CSR strategies (e.g., Arena, Azzone, \& Mapelli, 2019) and employees engagement in CSR (e.g., Rupp, et al., 2018), however less evidence is found in the literature regarding the role played by managers in CSR implementations (Vashchenko, 2015). Arnaud and Wasieleski (2014) emphasized that there is lack of understanding on how the managers change a general idea of CSR into company-specific CSR-related activities and initiatives through decision making. Therefore, understanding the factors affecting perceived individual ability to make a difference is crucial to promote socially responsible behaviour. This focus on analysis at individual-level meant towards revealing individual factors that mostly affecting their tendency to make decisions that mostly beneficial to others. 


\section{Literature Review}

\section{Socially Responsible Decision Defined}

Waldman and Siegel (2008, p. 117) asserted that CSR in general can be defined as "actions on the part of the firm that signal their willingness to advance the goals of identifiable stakeholder groups, such as employees, suppliers, local community, non-governmental organizations, or broader societal objectives (e.g., enhancing diversity or environmental performance)". Meanwhile, socially responsible decision (SRD) refers to a discretionary decisions and actions done by an individual with authority in organization to benefit the larger society (Crilly, Schneider, \& Zollo, 2008). "Individual with authority" in this context referring to executives and managers that hold decision making power in organizations. Schneider, Oppegaard, Zollo, and Huy (2005) elaborated in details regarding the key assumptions behind the definition of SRD. Firstly, it is based on individual choice, therefore they are personally responsible for their actions. Secondly, SRD results from intrinsic motivation. Thirdly, it is integrated in daily activities as a decision maker in organization, and last but not least, it relies on the individual's practical wisdom.

\section{Theories on Socially Responsible Decision}

This study mainly being supported by Stakeholder Theory and Theory of Planned Behavior.

\section{Stakeholder Theory}

Stakeholder Theory is not just a well-known theory in business ethics field, it is used as a part of the framework in explaining CSR methods such as ISO 26000 and Global Reporting Initiative (GRI) that involve stakeholder analysis (Duckworth, Holly Alison, Moore, 2010). Freeman (1984, p. 4) indicated that stakeholders are "those who can affect or is affected by the achievements of the organization's objectives". Stakeholders may include shareholders, customers, suppliers, distributors, employees, and local communities. According to Jones and Wicks (1999), Stakeholder Theory rely on four main assumptions. First, the firm has relationship with fundamental (stakeholder) groups that goes beyond shareholders (Jones, Wicks, \& Freeman, 2002); second, the process and outcomes associated with the relationships are based on the purpose of ensuring business long-term survivability and mutual benefit; third, the interests of all legitimate stakeholders have value and finally, the focus of Stakeholder Theory is on managerial decision-making. This will include the analysis of characteristics and behavior of organization, such as how companies are managed, how the board of directors looking corporate constituencies, the method manager thinks of management and the nature of the firm (Donaldson, Preston, \& Preston, 1995).

Stakeholder Theory can relates the usefulness of CSR initiatives to the business player. This approach enables companies to develop strategies consistent with stakeholder demands and, thus, ensuring organizational prosperity in the long run (Capece \& Costa, 2013). On top of that, this theory strongly highlights that all stakeholders must be considered in decision making process of the company.

In summary, Stakeholder Theory is related to the responsibility of management towards their stakeholders. Gupta, Briscoe and Hambrick, (2017) underlined two most important factors 
contributing toward management decision to behave responsibility towards stakeholder; their own self and encouragement from the organization. By applying stakeholder theory, the study will explain the responsibility of management especially those stakeholders involve in CSR decision making (i.e., manager) at the organization in Klang Valley.

\section{Theory of Planned Behavior}

Theory of Planned Behavior (TPB) justify the relationship between individual background factors (internal locus of control, cognitive moral development and empathic concern) with the studied behavior (SRD). TPB which originated from Theory of Reason Action (TRA) by (Ajzen \& Fishbein, 1980; Fishbein \& Ajzen, 1975) proposed that attitude is positively related to intention to conduct a particular behavior, in which intention and actual behavior are closely related to each other. TPB stressed the role of individual background factors (Fishbein \& Ajzen, 1975) that give impact on intentions and behavior. In brief, there are direct relationship and indirect relationship between background factors toward individual behavior. For instance, if one intends to behave in an environmentally responsible way, there is discrepancy of accessibility of facilities and infrastructures, perceived behavior control is low and constraints are increase, thus the behavior may not occur. Study done by (Liou \& Bauer, 2007) explain the obesity factors in overweight Chinese American.

Based on the above descriptions, TPB helps addressing the understanding of individual factors (internal locus of control, empathic concern and cognitive moral judgement) on socially responsible behavior by stakeholders in the organization.

\section{Determinants of Socially Responsible Decisions and Hypothesis Development Internal Locus of Control}

The notion of locus of control was developed by Rotter (1966). Locus of control deals with individual ability to control the main cause of the events in their life. It can be divided into internal and external locus of control. Internal locus of control referred as a belief that the events of the individuals resulted from their own personal behavior, traits and actions (Rotter, 1990). Meanwhile, external locus of control defined the outcome of the individual's perception is determined by fate, luck or other external environments that beyond his control. This study however will only be focusing on internal locus of control.

Individual with internal locus of control believe that they able to determine their future behaviour able to act alert towards environmental changes. Compared to external locus of control, they are more passionate in change the environments and they attribute more importance to their abilities, failures and achievements (SolmuS, 2004, p. 196). People with internal locus of control tend to change their life with their own efforts whereby individual will external locus of control tend to agonize from hopelessness in determine the direction of their life as they have faith in that some rewards in their life are not derived from the efforts like they are lucky or coincidence being in the right place at right time (SolmuS, 2004, p. 196). Locus of control is an important variable to explain the human behaviour in organization (Fagbola \& Popoola, 2015). 
Various studies have discovered that individuals with internal locus of control face less difficulty to express their feelings. Instead, they have more self-confidence and are neglect the need of others' approval upon themselves, they more concerned on their physical and mental health. Ashby, Kottman and Draper (2002) identified that people with external locus of control undergo more anxiety, stress and depression that they cannot avoid favourable events from happen. Individual with internal locus of control accept responsibility for events (Bernardi, 2001) and display more active behavior against problem solving (Anderson, 1977). There was evidence that employee with internal locus of control are confident with their efficiency and competence that show their capabilities in making decisions to solve problem and taking essential steps (SolmuS, 2004, p. 197). Internal locus of control is a personality traits that may affect the decision making process (Thompson, 2000). Research done by Dumitriu, Timofti, Nechita and Dumitriu (2014) proved that individual with internal locus of control that adopt leadership style centered on tasks, show pragmatic spirits, perseverance and achieving objectives tend to apply new efficient procedures in making decisions, organizing their own work and the subordinates. Akpochafo (2017) findings indicated that students with internal locus of control have high efficiency in conquering difficulties of their surrounding and pressure at school, have superior potential to overcome stress. Trevino (1986) conclude that manager with internal locus of control exhibit more consistency between moral judgement and action rather than the external locus of control.

Hereby, the internal locus of control in the study defined as the notch of an individual to control over their outcomes of event throughout their lives that might affect during the process of making decision in the organization.

\section{Internal Locus of Control and Socially Responsible Behavior}

Both Bray, Johns, and Kilburn (2011) and Smith, Hume, Zimmermann, and Davis (2007) claimed that individual ethical decision making was effected by their perceived locus of control. According to (Smith et al., 2007), individual with locus of control tend to have confidence in the existence between action and consequences. These individual responds more ethically when facing with dilemmas. Meanwhile, study done by Trevino and Youngblood (1990) revealed that individual with internal locus of control display low level unethical behavior and do what they think is right. Study done by Midlarsky and Midlarsky (1973) prove that people with internal locus of control facilitates helping behavior and they was suitable for complex tasks like managerial and professional jobs that required high learning abilities and the abilities in solving complicated information (Robbins, 2001). Coban \& Hamamci (2006) summarize that individual with internal locus of control using logical decision-making strategy frequently. Thus, our first hypothesis is stated as follows:

H1. There is a significant and positive relationship between internal locus of control and SRB among managers in Klang Valley. 


\section{Empathic Concern}

Concept of empathy have developed by theorist and psychologists past few decades (Duan \& Hill, 1996; Gladstein, 1977; 1983). Being selflessness and concern for others defined as empathic concern by Davis (1983). According to Woltin et al, (2011) and Stocks et al., (2011) empathic concern been described as an emotional response of compassion and concern causes by witnessing someone else in need. Several researchers agree that empathy involves an individual's understanding of another person's experience or the sensing of another person's emotions. Duan and Hill (1996) assumed different empathic levels based on function of inheritance or environmental experiences. Empathy involves emotional and non-emotional components that seen as personality and cognitive ability due to multiple characteristics (Davis, 1983a; 1983b).

To understand the nature and structure of empathy, empathy are constituted into two components (Jolliffe \& Farrington, 2006). Cognitive empathy that defined as the cognitive skills are being recognized and understand how another is feeling (Hogan, 1969). Next, affective empathy focused on the sharing emotional state of others (Baron-Cohen \& Wheelwright, 2004; Feshbach, 1975). Empathic concern not just involve empathizing but also requires a concern for another person (Chismar, 1988). Hence, empathic concern lies under affective empathy. Empathic concern able to motivate the helping behavior (Eisenberg \& Eggum, 2009) when the aversive feeling suppressed (Batson, Early, \& Salvarani, 1997; Ruby \& Decety, 2004), accompanied by the urge to take action to help to improve the other person's conditions (de Waal, 2008).

Further evidence from past studies with adult summarized that empathic concern does change an individual's decision making. Study done by Batson, Klein, Highberger and Shaw (1995) using college students offered good task to the worker rather than using random assignment when asked to consider the feeling of a worker who had recently suffered hardship. Verhaert and Van den Poel (2011) found a connection between empathic concern and donation decisions. Cecchetto, Korb, Rumiati and Aiello (2018) assured that the intensity of emotional reactions evoked by moral decision is biased by individual's empathic concern. Hence, these literatures confirmed that empathic concern does have their role in affecting the decision-making process of an individual.

Therefore, the concept of empathic concern in this study refer as the tendencies for the individual respondents to experience feelings of warmth, compassion and concern for others undergoing negative experiences.

\section{Empathic Concern and Socially Responsible Behavior}

Studies have been done in investigating the relationship between empathic concern and socially responsible behavior. In Cohen (2010) study, it was found that higher levels of empathic concern tend to disapprove of unethical negotiation tactics. In line this, studies by Cote, Piff and Willer, (2013) and Gleichgerrcht and Young (2013) found that individual under utilitarian judgement felt less empathic concern toward the individual they sacrificed for the sake of the group. The result by Kemple (2016) indicated that the empathy controlling and weaken the relationship between psychopathy and moral decision making. 
The findings of Dietz and Kleinlogel (2014) study noted that perspective taking and empathic concern was weakly associated with struggling a supervisor's request to cut employee pay. Batson (2011) suggested that empathic concern is one of the motivation on high prosocial human behavior when associated with high costs to the individual. Hence, the hypothesis of this study is;

H3. There is a significant and positive relationship between empathic concern and SRB among managers in Klang Valley.

\section{Cognitive Moral Development}

The notion of Cognitive Moral Development is introduced by the theory of moral development by (Kohlberg, 1969) argued that all people are characterized by different level of cognitive moral development that influence the way of people making decisions in complex situation of conflict of interests.

Kohlberg's theory on moral development has been widely applied in psychology, business ethics and even feminist studies. Kohlberg's theory assists business managers to understand the interaction between stakeholders (including employees) and the organization. in the same time, this theory illustrated their leadership at different growth stages when they were developed. There are three main level of Kohlberg's of moral development; Preconventional Morality, Conventional Morality and Post-Conventional Morality.

Punishment and rewards act as motivator by managers at the first level of CMD (Preconventional level). The managers would prefer in monitoring and incentives as they are evaluating through moral dilemmas of how they can earn from the situation and be punished for not doing what they are required to. To conclude, first level of moral development of an individual are characterized with low and weak principles where they choose the course of action that is benefits to themselves, families and friends.

At other levels of CMD, managers tend to have certain values that move beyond personal wealth maximization. Level 2 individuals (conventional) are more pro-social and consider the interests of the group (teammates, organization, community and etc) in evaluating possible options and make decisions. For level 3, individuals have their moral principles that go through serving their internal group. Most of the individual at these stages would make actions that they perceived to be legal, ethical and fair according to their moral values.

CMD considered a stable characteristic that would change much in people who has reached the age of maturity (Rest, 1979). The higher the level of moral development, the lesser the tendency of manager approach in opportunistic behavior like shirking and using corporate resources to serve their personal goals (Aleksey Martynov, 2009).

\section{Cognitive Moral Development and Socially Responsible Behavior}

It was found that high levels of moral reasoning significantly related to behavior in organization. For instance, the actions of helping the others and decrease in cheating (Trevino, 1986) and ethical decision making (Trevino \& Youngblood, 1990). Study done by Underwood and 
Moore (1982) indicated that individual with developed moral reasoning tend to have better understanding the perspective of others. on the other hand, studies have found moderate relationship between moral reasoning and actual behavior (Rest, 1986; Ryan, 2001; Blasi, 1980). As mentioned by Colby and Damon (1992) that people still exhibit moral character or integrity without being assessed at Kohlberg's highest level of moral reasoning. But, thought the relationship between them as not strong, there is still positive connection between moral reasoning and socially responsible behavior. Therefore, the second hypothesis of this study is:

H2. There is significant and positive relationship between cognitive moral development and SRB among managers in Klang Valley.

\section{Research Framework}

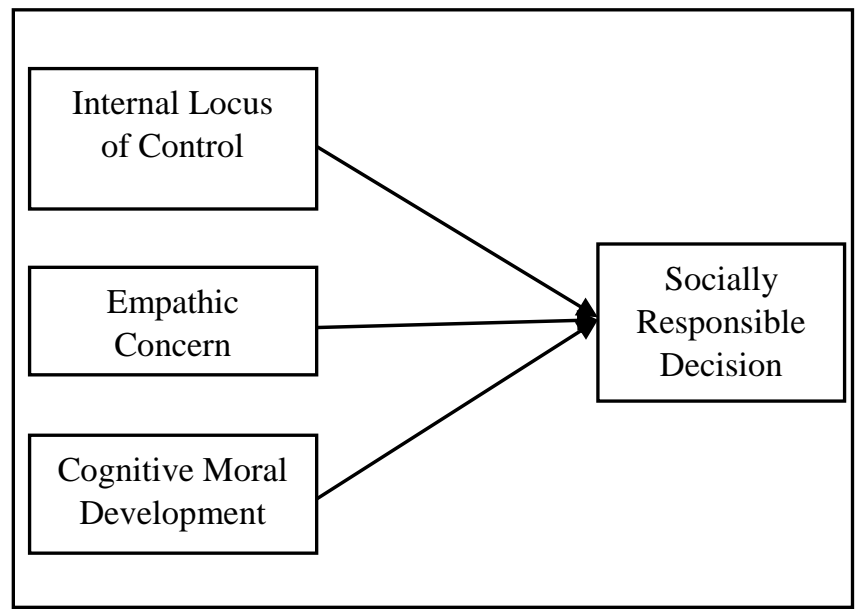

Figure 1. Research Framework of the Study.

Figure 1 illustrates the relationship between the IVs and the DV.

\section{Materials and Methods}

The study was conducted based on quantitative technique using correlational descriptive research design among managers from selected Malaysian Public Listed Companies (PLC) located in Selangor. It was estimated that there were in average of 5 executives and managers involved in decision making process for each organization. To date, there are about 252 PLC in Selangor $(\mathrm{N}=1260)$. The sample size in this study was determined by using $\mathrm{G}^{*}$ power. The researcher has specifying the values of effect size, $r=.15$ (large size), a significant alpha, $\alpha=.05$, power $=.95$. The prior analysis has calculated a total sample required as 119 . A sum of 150 questionnaires were distributed and 89 sets of questionnaires were returned back, giving response rate of $74.8 \%$. However, only 73 sets of questionnaires were valid for this study. 


\section{Instruments and Measurement}

\section{Instrument for Socially Responsible Decisions}

SRD in this study referred as individual manager preferences conscientiously supporting CSR initiatives in his decisions within the organization. Instrument for SRD has been adopted from the Melbourne Decision Making Questionnaire developed by Mann et al. (1998). For the purpose of this study, the original items in the instruments have been amended accordingly to suit the current research context. The internal consistency of internal locus of control is consider good (Cronbach's alpha $\geq .70$ ). The scale used a type response format of 5-point Likert scale.

\section{Internal Locus of Control}

Internal locus of control is operationalized as the degree of a person to control over their outcomes of event throughout their lives. For this factor, Levenson Multidimensional Locus of Control Scales by Levenson (1972) was adopted and adapted for this study. This study only emphasized in internal locus of control scales and thus, 8 items were used for internal locus of control. The internal consistency of internal locus of control is consider good (Cronbach's alpha $\geq .70)$.

\section{Empathic Concern}

Empathic concern in this study defined as the tendencies for the individual respondents to experience feelings of warmth, compassion and concern for others undergoing negative experiences. Davis (1983) developed a questionnaire to measure empathy among adult. Considering the objectives and its analysis, this study utilized the shorten version of empathic concern and been adapted to suit this study. Internal consistency of this instrument is considered acceptable (Cronbach's alpha $\geq .70$ ).

\section{Cognitive Moral Development}

In this study, cognitive moral development defined as the individuals' ability in determining difference between right and wrong that affect their actions upon others. For cognitive moral development, Moral Development Scale for Professionals by Soderhamn, Bjornestad, Skisland and Cliffordson (2011) consist of 12 items that measure the Kohlberg's Cognitive Moral Development Stages. Thus, this instrument was employed to measure the variables. Internal consistency of this instrument is considered acceptable (Cronbach's alpha $\geq .70)$.

\section{Data Collection Procedure}

There are 150 questionnaires were distributed to 30 randomly selected companies that conducted CSR activities as the respondents of the study. 89 sets of questionnaires were return back by the respondents. Yet, only 73 questionnaires were valid for this study. The questionnaires were distributed by first week of April 2018 after the pilot study has been successfully conducted and reliable. The distribution of the questionnaire splits into two ways; (1) through hardcopy by visiting the companies and (2) softcopy via emails to the person or department who involves in 
CSR. The data were successfully collected within one month and 12 days (until 14 May 2018).

Each respondent was given the informed consent letter as get approval from the organizations in order to answer the survey questionnaire. The administration of all the tests was conducted by the researcher herself with the help of supervisor. The researcher ensured that the confidentiality in the cover page enclosed was explained to the respondents to prevent any response error. The participation of this study is completely voluntary. In return, a copy of result findings will be given to the organization as a token of appreciation for their participations in this study.

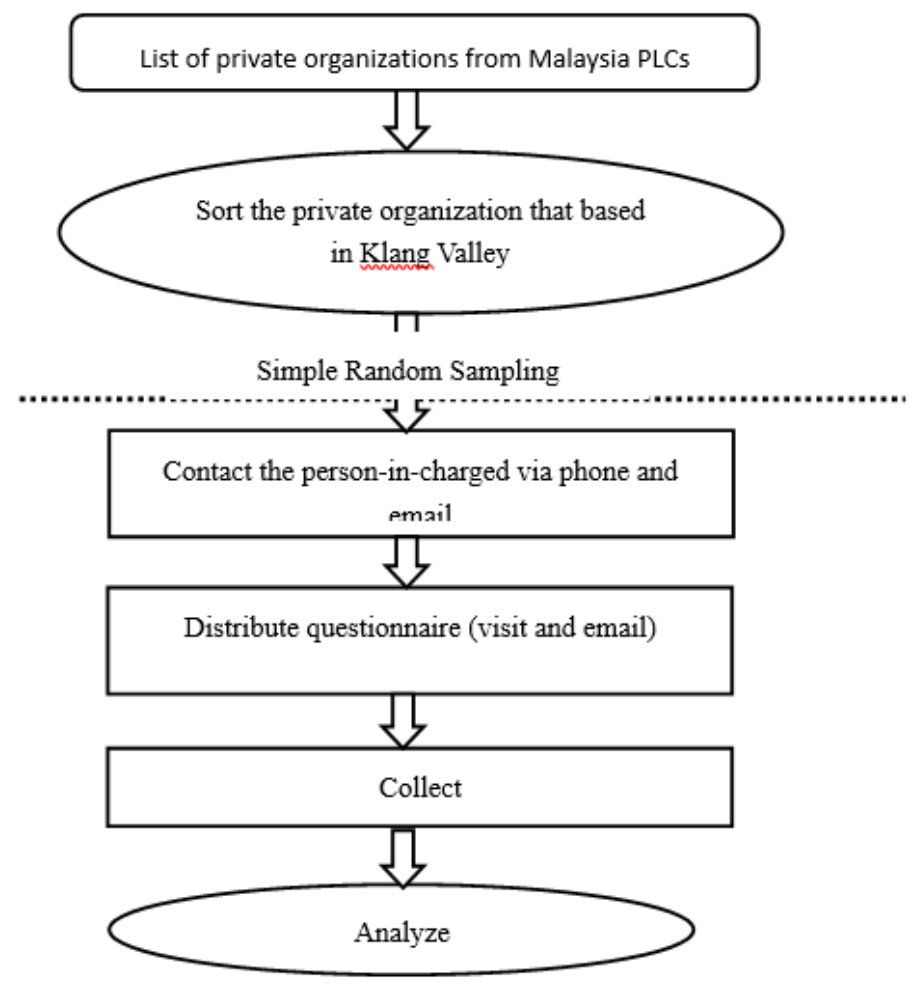

Figure 2. Flow Chart of Data Collection Procedures

\section{Findings and Discussion}

\section{Demographic Profile of Respondents}

Table 1 displayed the demographic information of the respondents of this study. Most of the respondents are under 31 to 40 age group with highest percentage, 34.2\%. However, 16 respondents choose not to reveal their age due to personal data protection act based on their organizations. Similarly, the respondents of this study were about equal distribution among female and male. The findings further indicate that majority (37\%) of respondents had less than 11 years of working experience as manager compared to $28.8 \%$ (21) of respondents who had 11 years to 20 years of working experience as managers. Only $5.5 \%$ (4) of respondents who had more than 30 years of working experience as manager. 
INTERNATIONAL JOURNAL OF ACADEMIC RESEARCH IN BUSINESS AND SOCIAL SCIENCES

Vol. 9, No. 11, November, 2019, E-ISSN: 2222-6990 @ 2019 HRMARS

Table 1. Demographic Profiles of the Respondents $(n=73)$

\begin{tabular}{lcc}
\hline Profile & Frequency & Percentage \\
\hline Age & 0 & \\
$<20$ & 13 & 0.0 \\
$21-30$ & 25 & 17.8 \\
$31-40$ & 19 & 34.2 \\
$41-50$ & 16 & 26.0 \\
Undisclosed & & 21.9 \\
\hline Gender & 32 & \\
Male & 37 & 43.8 \\
Female & 4 & 50.7 \\
Undisclosed & & 5.5 \\
\hline Working Experience & 27 & \\
Less than 11 years & 21 & 37.0 \\
11 years-20 years & 13 & 28.8 \\
21 years- 30 years & 4 & 17.8 \\
More than 30 years & 8 & 5.5 \\
Undisclosed & & 11.0 \\
\hline
\end{tabular}

\section{Descriptive Analysis}

The computed mean scores were derived into three levels, low (1.00-2.33), moderate (2.34-3.67), and high (3.68-5.00). As shown in Table 2, the result illustrated that majority of respondents perceived high socially responsible decision $(M=3.91, S D=0.60)$, internal locus of control $(M=3.72, S D=0.49)$, emphatic concern $(M=3.73, S D=0.47)$, and cognitive moral development $(\mathrm{M}=3.77, \mathrm{SD}=0.41)$. 
INTERNATIONAL JOURNAL OF ACADEMIC RESEARCH IN BUSINESS AND SOCIAL SCIENCES

Vol. 9, No. 11, November, 2019, E-ISSN: 2222-6990 @ 2019 HRMARS

Table 2. Level of Variables $(n=73)$

\begin{tabular}{|c|c|c|c|c|}
\hline Variable & $f$ & $\%$ & M & SD \\
\hline Socially Responsible Decision & & & 3.91 & .60 \\
\hline Low (1.00-2.33) & 0 & 0.0 & & \\
\hline Moderate (2.34- 3.66) & 26 & 35.6 & & \\
\hline High (3.67-5.00) & 47 & 64.4 & & \\
\hline Internal Locus of Control & & & 3.72 & .49 \\
\hline Low (1.00-2.33) & - & - & & \\
\hline Moderate (2.34- 3.66) & 31 & 42.5 & & \\
\hline High (3.67-5.00) & 42 & 57.5 & & \\
\hline Empathic Concern & & & 3.73 & .47 \\
\hline Low (1.00-2.33) & - & - & & \\
\hline Moderate (2.34- 3.66) & 30 & 41.1 & & \\
\hline High (3.67-5.00) & 43 & 58.9 & & \\
\hline Cognitive Moral Development & & & 3.77 & .41 \\
\hline Low $(1.00-2.33)$ & - & - & & \\
\hline Moderate (2.34- 3.66) & 28 & 38.4 & & \\
\hline High (3.67-5.00) & 45 & 61.6 & & \\
\hline
\end{tabular}

Results indicated that majority of the respondents actively involved

\section{Pearson Correlation Analysis}

Pearson Product Moment Correlation was used in this study in measuring the strength and direction of relationship between variables. Pearson Correlation coefficient $(r)$, provides a meaningful index for indicating relationship, with the sign of the coefficient indicating the direction of the relationship, and the difference between the coefficient and 0 indicating the degree of the relationship.

\section{Research Objective 3}

To determine the relationship between individual factors and socially responsible behavior among managers in Klang Valley.

Based on Table 3, all individual factors (internal locus of control, empathic concern and cognitive moral development) have positive relationship toward socially responsible behavior among managers. This conclude that high internal locus of control, empathic concern and cognitive moral development will increase socially responsible behavior among managers in Klang Valley. Back to Cohen (1988), when value of magnitude between two variables are in the range of $0.3-0.49$, moderate relationship was formed between them. The results indicate that internal locus of control, empathic concern and cognitive moral development have moderate 
relationship with socially responsible behavior. Based on these individual factors, cognitive moral development (0.437) has the highest relationship on socially responsible behavior compared to internal locus of control (0.384) and empathic concern (0.301).

Table 3. Intercorrelations between Individual Factors and Socially Responsible Behaviour

\begin{tabular}{lllll}
\hline \multicolumn{1}{c}{ Variables } & $\mathbf{1}$ & $\mathbf{2}$ & $\mathbf{3}$ & $\mathbf{4}$ \\
\hline 1. Internal Locus of Control & - & $.265^{*}$ & $.406^{* *}$ & $.384^{* *}$ \\
2. Empathic Concern & & - & $.576^{* *}$ & $.301^{* *}$ \\
3. Cognitive Moral Development & & - & $.437^{* *}$ \\
4. Socially Responsible Behavior & & & & - \\
\hline
\end{tabular}

**. Correlation is significant at the 0.01 level (2-tailed).

*. Correlation is significant at the 0.05 level (2-tailed).

H1: There is significant relationship between internal locus of control and socially responsible behavior among managers in Klang Valley.

As depicted in Table 4, the result indicated that internal locus of control was found to have a significant effect on socially responsible behavior among managers in Klang Valley. Thus, the Hypothesis 1 was supported.

H2: There is significant relationship between empathic concern and socially responsible behavior among managers in Klang Valley.

As illustrated in Table 4, the result showed that empathic concern was found a significant relationship with socially responsible behaviour among managers in Klang Valley. Therefore, the Hypothesis 2 was supported.

H3: There is significant relationship between cognitive moral development and socially responsible behavior among managers in Klang Valley.

Based on the result shown in Table 4, the result indicated that cognitive moral development was found to have a significant effect on socially responsible behavior among managers in Klang Valley. Thus, the Hypothesis $\mathbf{3}$ was supported.

\section{Research Objective 4}

To determine the best prediction factor that influencing socially responsible behavior among managers in Klang Valley.

Table 4 below indicates $R^{2}$, the coefficient of determination is 0.24 explain that $24 \%$ of the variance in internal locus of control, empathic concern and cognitive moral development towards socially responsible behavior. Frost (2015) mentioned that R-squared is a measurement of determine the closeness of the data that fit to the regression line. The higher the R-squared, the 
better model fit in the data. However, he explained that there are certain field that gained low Rsquared especially under the field who try to test the human behaviour in psychological way. In a simple way to explain, human behaviour is hard to be predicted. Approximately $24 \%$ of total variance in socially responsible behavior was accounted by internal locus of control, empathic concern and cognitive moral development, $F(3,69)=7.437, p<.05$. The correlation between internal locus of control $(\beta=.245, p<.05)$ and cognitive moral development $(\beta=.301, p<.05)$, and socially responsible behavior were statistically significant. However, empathic concern $(\beta=.063$, $p>.05$ ) was found not significantly affect socially responsible behavior.

Table 4. Multiple Regression Analysis

\begin{tabular}{|c|c|c|c|c|c|c|c|}
\hline \multirow[t]{2}{*}{ Variable } & \multicolumn{2}{|c|}{ Unstandardized Beta } & \multirow{2}{*}{$\begin{array}{l}\text { Std. } \\
\text { Beta }\end{array}$} & \multirow[t]{2}{*}{$t$} & \multirow[t]{2}{*}{$p$} & \multicolumn{2}{|c|}{$\underline{95 \% \mathrm{Cl}}$} \\
\hline & $\boldsymbol{B}$ & Std. Error & & & & LB & UB \\
\hline SRB & .816 & .671 & & & & -.521 & 2.154 \\
\hline ILOC & .303 & .142 & $.245^{* *}$ & 2.138 & 0.036 & .020 & .586 \\
\hline EC & .082 & .166 & .063 & 0.493 & 0.624 & -.249 & .412 \\
\hline CMD & .439 & .198 & $.301 * *$ & 2.223 & 0.029 & .045 & .834 \\
\hline
\end{tabular}

$\mathrm{F}(7.437), \mathrm{R}^{2}=.244, .211$

Study by du Prel, Hommel, Rohrig, and Blettner (2009) stated that confidence intervals (Cl) indicate the direction of the effect studied. With the help of $\mathrm{Cl}$, the significance of the relationship was determined. If the confidence interval does not include the value of zero, it can be assumed that there is statistically significance result on the variables. Table 4 revealed that the range of lower bound to upper bound of internal locus of control and cognitive moral development does not include zero value and thus, the relationship between internal locus of control and cognitive moral development toward socially responsible behavior are significant. However, the range of $\mathrm{Cl}$ of empathic concern involves zero values and hence, there is no significant relationship between empathic concern on socially responsible behavior among managers in Klang Valley.

In addition, the result in Table 4 showed that the cognitive moral development has highest values of standardized beta (.301) compared to internal locus of control (.245) and empathic concern (.063). Therefore, based on Table 4, cognitive moral development has the strongest influence on socially responsible behavior among managers in Klang Valley.

\section{Discussion of Findings}

This current section will provide further discussion on the finding of the study, aligning with research objectives. Further discussions are explained as follows;

\section{Internal Locus of Control}

Following suggestion by Afolabi and Alade (2015), these scores could be grouped in three 
levels, namely, low (1.00-2.00), moderate (2.34-3.66), and high (3.67-5.00). Overall mean = 3.7175 (considered high). Colquitt, LePine and Wesson (2015) studies revealed that employee with internal locus of control mostly satisfied with their job and they perform better.

In fact, having internal locus of control able to differentiate effective and ineffective leaders, managers and employees. With high internal locus of control, managers tendencies to provide better solution for business problems are high and even they show good leadership and manage organizations better (Julita \& Rafaei, 2009).

\section{Empathic Concern}

Followed by empathic concern, the overall mean score is under high empathic concern. In Scott, Colquitt, Paddock, \& Judge (2010) research, manager with empathic concern will foster a climate of understanding and support that leads to greater happiness following daily accomplishments at work. The result supported Kleinlogel and Dietz (2014) study, argued that individual with high empathic concern understood how other person felts and would take this account in their decision making. The findings imply that empathic concern could play critical role in making decision among managers.

\section{Cognitive Moral Development}

Same goes to cognitive moral development, the mean score (3.771) is high among managers. Higher level of cognitive moral development are tend to not respond with the rewards and punishment as a means of controlling their behavior (Aleksey Martynov \& Logachev, 2016). According to Orlitzky and Swanson (2006, p.10) individual with high CMD are more readily to reflect on moral obligation that exceed the legal realm to taken into account broader social and environmental concerns.

\section{Influence of Individual Factors on Socially Responsible Behavior Internal Locus of Control and Socially Responsible Behavior}

The Pearson correlation analysis revealed that the internal locus of control was found to have a significant effect on socially responsible behavior $(r=.384, p=0.000)$. According to Hughes, Ginnette and Curphy (2012), individual with internal locus of control exhibit participate behavior. Employees with internal locus of control can see the relationship contingencies between their actions and outcomes/rewards, and thus are more likely to make ethical decisions (Manley, Benavidez, \& Dunn, 2007). When they feel their actions could determine other's event, they tend to make decision on which activities to be conducted as a part of CSR approach. This finding of the study supported Ornoy (2010) that internal locus of control positively associated to an attitude towards taking part in decision making at work. Their characteristics may impact a manager's preferences for ambiguity and processing of information and thereby, the decision making styles (Thompson, 2010). Moreover, Adekola (2012) restate locus of control of an employee influence their decision making quality. A good leader makes their job clear to everyone, able to foresee difficulty and take actions to avoid them, the direct link between how hard one work and the output; teamwork is an outstanding way to create character and expand 
productivity; when I make plan I almost certain that I can make them work.

\section{Empathic Concern and Socially Responsible Behavior}

The Pearson correlation analysis revealed that the empathic concern was found significant and positive effect on socially responsible behavior $(r=0.301, p<0.05)$. The finding of the study supports the research by Kleinlogel and Dietz (2014). Findings of their study concluded that organization which practiced empathy can enhance ethical of the decision-making process and altruistic behavior within organization. Highly empathic individual has higher tendency to consider another's feelings and more likely to help others.

Empathy play role in participate the decision-making process whether to cut wages or to keep them for to create value for all stakeholders. In fact, manager with high level of empathic concern tend to form ethical intentions especially concern with employee health and well-being (Mencl \& May, 2009). Pavlovich and Krahnke (2012) added that empathy allows people to develop mutual agreement and avoid personal judgment, that resulting in connectedness and compassion within organization.

\section{Cognitive Moral Development and Socially Responsible Behavior}

The Pearson correlation analysis (Table 3 ) revealed that the cognitive moral development was found to have a significant effect on socially responsible behavior $(r=0.437, p<0.05)$. the findings prove that cognitive moral development does influence the manager's preference in corporate social responsibility initiatives. The result is similar to study by Loe, Ferrell and Mansfield (2000) which they found out that individual moral philosophy significantly influenced ethical decision making. Needless to say, when an individual has higher level of cognitive moral development, the effect of self-construal and temporal construal on their decision making will become stronger that those who have lower level of cognitive moral development (Qian, 2014).

\section{Summary}

The result of the study revealed that internal locus of control and cognitive moral development had a significant relationship to socially responsible behavior. Meanwhile, empathic concern was found no significant relationship toward socially responsible behavior among managers. In addition, the result indicated that internal locus of control, empathic concern and cognitive moral development have positive and moderate relationship toward socially responsible behavior. Among these factors, only empathic concern has no significance relationship on socially responsible behavior.

Finally, the result shown that cognitive moral development was the best factors in affecting socially responsible behavior among managers compared to internal locus of control.

\section{Conclusion of the Study}

There is growing concern with socially responsible behavior through the application of Human Resource Development (HRD) concepts and practices (refer the article I downloaded). Taking into account the modern HRD perspective which includes individual organizational 
development as one of the components in the framework, the study examined the factors influencing socially responsible behavior. The following conclusion were drawn from the study.

1. Socially responsible behavior is important in determine the CSR decision making done by manager in organization. Any decision done by the manager will influence to the financial performance, and corporation image of the organization

2. Internal locus of control significantly influences socially responsible behavior among manager. The result explained that manager who have high control over their outcomes of event throughout their lives, they tend to make better in CSR decision making at their organization.

3. The study reviewed that cognitive moral development has significant effect on socially responsible behavior compared to other individual factors among managers in Klang Valley. It concludes that moral reasoning is the most important among manager to take into account when make decision based on right and wrong judgement.

\section{Implication of the Study}

The study enables to gain deeper and comprehensive understanding on the socially responsible behavior among managers. The result of the study supplies important implication in both theoretical and practical implications for researcher to deliberate.

\section{Theoretical Implication}

The findings of the study are supported the theory that internal locus of control, empathic concern and cognitive moral development affecting the socially responsible behavior among managers in Klang Valley. This study extends the Stakeholder Theory by clearly clarifies individual factors that would broaden and strengthen up the responsibility as stakeholder to explain individuals' socially responsible behavior among managers.

Theory of Planned Behavior employed to support Stakeholder Theory in this study. the findings revealed support for the employment of the Theory of Planned Behavior in the research framework of this study as the theory. It implies that individual factors are important in enhancing what leads to social responsible behavior among manager in Klang Valley.

To conclude, this study has contributed to the practical use of Stakeholder Theory and Theory of Planned Behavior in an integrative manner on developing the knowledge of the phenomenon of socially responsible behavior among managers in Klang Valley.

\section{Practical Implication}

This study contributes to current perspective of Human Resource Development on individual development. Most of CSR well known with the Global Reporting Analysis and CSR disclosure to indicate how frequent an organization exercise their responsibility. Thus, less attention has been focused on individual level perspectives. This gap should be highlighted as the initiatives has been done by individually. The study proved that individual personal factors were directly influence the socially responsible behavior. 
Socially responsible behavior will give impact to the employee relationship, sharing of knowledge and ethical culture while performing CSR activities in organization. SRB is very important in enhancing employee engagement, commitment and loyalty towards their work.

\section{Recommendation for Future Research}

As this study able to attain limited number of managers to investigate the relationship between individual factors and socially responsible behavior, it is recommended that future studies could done with bigger sample size in order to have greater statistical confidence. Current study only implies individual's perspective of socially responsible behaviour in organization. Putting into larger picture, it is recommended that future study could be done with additional organizational variables that influence the CSR decision making done by the management. In fact, socially responsible behavior is likely to occur in organization setting. Therefore, it is an opening for future researchers to widen the area of organizational factors based on theories such as institutional theory. Taken all into account, it can be resulted in more complex and interesting findings. For instance, organizational culture (Pierce \& Snyder, 2015) could impact how employees feel and influence the decision making of its employees. Other than cultures itself, peer pressures within an organization could affected a person's ethical decision making (Tillman, Hood, Lawrence, \& Kacmar, 2015). It is also suggested that social networking could set as moderator or mediator in influencing an individual's moral behavior.

A survey through questionnaires was conducted in this study to determine the relationship between individual factors with socially responsible behavior among managers in private organization located at Klang Valley. Thus, it is recommended that future studies may consider to conduct the research in other location in Malaysia such as Penang and Johor Bharu. Both locations are also well known in conducting CSR practices especially among private organizations.

Socially responsible behavior is considered as complex construct that reflects various factors related to individual and social interaction. It is recommended that future studies should be carried out by adding other predictors of socially responsible behavior such as gender, age, personality and physical health status. Gender might impact on a person moral reasoning and ethical decision making (Boulouta, 2013; Burleson \& Robbins, 2015).

This study employed quantitative research method to attain statistical generation on relationship between individual factors and socially responsible behavior of managers. As the study conducted based on cross section of point in time, it is recommended that future researchers to enforce for qualitative to contact with deeper understanding on how individual interests and preference affecting socially responsible behaviour.

\section{Acknowledgement}

The research was funded by Putra Grant-Young Lecturer Initiative (GP-IPM) 2017-2019 of Universiti Putra Malaysia 
INTERNATIONAL JOURNAL OF ACADEMIC RESEARCH IN BUSINESS AND SOCIAL SCIENCES

Vol. 9, No. 11, November, 2019, E-ISSN: 2222-6990 @ 2019 HRMARS

\section{Corresponding Author}

Siti Noormi Alias (PhD), Department of Professional Development and Continuing Education, Faculty of Educational Studies, Universiti Putra Malaysia (UPM), Malaysia

Email: sitinoormi@upm.edu.my

\section{References}

Adekola, E. O. (2012). Role of locus of control in effective decision-making of managers in public enterprises. Personnel Management Journal, 15(3), 210-219.

Ajzen, I., \& Fishbein, M. (1980). Understanding attitudes and predicting social behavior. Understanding attitudes and predicting social behavior.

Akpochafo, G. O. (2017). Locus of Control as Correlate of Career Decision Making among Secondary School Students in Delta State of Nigeria. Journal of Educational and Social Research, 7(2).

Anderson, C. R. (1977). Locus of control, coping behaviors, and performance in a stress setting: a longitudinal study. Journal of Applied Psychology, 62(4), 446-451.

Arena, M., Azzone, G., \& Mapelli, F. (2019). Corporate Social Responsibility strategies in the utilities sector: A comparative study. Sustainable Production and Consumption, 18, 83-95.

Arnaud, S., \& Wasieleski, D. M. (2014). Corporate Humanistic Responsibility: Social Performance Through Managerial Discretion of the HRM. Journal of Business Ethics, 120(3), 313-334.

Ashby, J. S., Kottman, T., \& Draper, K. (2002). Social Interest and Locus of Control: Relationship and Implications. The Journal of Individual Psychology, 58(1), 52-61.

Baron-Cohen, S., \& Wheelwright, S. (2004). The empathy quotient: An investigation of adults with asperger syndrome or high functioning autism, and normal sex differences. Journal of Autism and Developmental Disorders.

Barrena Martínez, J., López Fernández, M., \& Romero Fernández, P. M. (2016). Corporate social responsibility: Evolution through institutional and stakeholder perspectives. European Journal of Management and Business Economics, 25(1), 8-14. https://doi.org/10.1016/j.redee.2015.11.002

Batson, C. D. (2011). Altruism in Humans. Altruism in Humans.

Batson, C. D., Early, S., \& Salvarani, G. (1997). Perspective Taking: Imagining How Another Feels Versus Imaging How You Would Feel. Personality and Social Psychology Bulletin, 23(7), 751-758.

Batson, C. D., Klein, T. R., Highberger, L., \& Shaw, L. L. (1995). Immorality From Empathy-Induced Altruism: When Compassion and Justice Conflict. Journal of Personality and Social Psychology, 68(6), 1042-1054.

Bernardi, R. A. (2001). A theoretical model for the relationship among: stress, locus of control. Business Forum, 26, 27-33.

Blasi, A. (1980). Bridging moral cognition and moral action: A critical review of the literature. Psychological Bulletin, 88(1), 1-45.

Boulouta, I. (2013). Gender diversity and corporate social performance. Journal of Business Ethics, 113(2), 185-197. 
Boulouta, I., \& Pitelis, C. N. (2014). Who needs CSR? The impact of corporate social responsibility on national competitiveness. Journal of Business Ethics, 119(3), 349-364.

Bray, J., Johns, N., \& Kilburn, D. (2011). An Exploratory Study into the Factors Impending Ethical Consumption. Journal of Business Ethics, 98(4), 597-608.

Burleson, J., \& Robbins, T. (2015). Consideration of Future Consequences: A Closer Look at Gender and Cultural Differences. International Journal of Business and Social Science, 6(5), 1-6.

Capece, G., \& Costa, R. (2013). The new neighbourhood in the internet era: Network communities serving local communities. Behaviour and Information Technology, 32(5), 438-448.

Carroll, A. B., \& Shabana, K. M. (2010). The business case for corporate social responsibility: A review of concepts, research and practice. International Journal of Management Reviews, 12(1), 85-105.

Castka, P., Balzarova, M. A., Bamber, C. J., \& Sharp, J. M. (2004). How can SMEs effectively implement the CSR agenda? A UK case study perspective. Corporate Social Responsibility and Environmental Management.

Cecchetto, C., Korb, S., Rumiati, R. I., \& Aiello, M. (2018). Emotional reactions in moral decisionmaking are influenced by empathy and alexithymia. Social Neuroscience, 13(2), 226-240.

Chismar, D. (1988). Empathy and sympathy: The important difference. The Journal of Value Inquiry, 22(4), 257-266.

Cho, S. J., Chung, C. Y., \& Young, J. (2019). Study on the relationship between CSR and financial performance. Sustainability, 11(2), 343-368.

Clarkson, M. E. (1995). A stakeholder framework for analyzing and evaluating corporate social performance. Academy of Management Review, 20(1), 92-117.

Coban, A. E., \& Hamamci, Z. (2006). Investigation of Focal Points in Terms of Different Strategies for the Locus of Control Adolescents Decision. Kastamonu Education Journal, 14(2), 393402.

Cohen, T. R. (2010). Moral emotions and unethical bargaining: The differential effects of empathy and perspective taking in deterring deceitful negotiation. Journal of Business Ethics, 94, 569-579.

Colby, A., \& Damon, W. (1992). Some do care: Contemporary lives of moral commitment. New York: Free Press, 1992.

Colquitt, J. A., LePine, J. A., \& Wesson, M. J. (2015). Organizational behavior: Improving performance and commitment in the workplace (4th ed.). New York: McGraw-Hill Education.

Cote, S., Piff, P. K., \& Willer, R. (2013). For whom do the ends justify the means? Social class and utilitarian moral judgment. Journal of Personality and Social Psychology, 104, 490-503.

Crilly, D., Schneider, S. C., \& Zollo, M. (2008). Psychological antecedents to socially responsible behavior. European Management Review, 5(3), 175-190. https://doi.org/10.1057/emr.2008.15

Cullinan, C., Bline, D., Farrar, R., \& Lowe, D. (2008). Organization-harm vs. organization-gain ethical issues: An exploratory examination of the effects of organizational commitment. 
INTERNATIONAL JOURNAL OF ACADEMIC RESEARCH IN BUSINESS AND SOCIAL SCIENCES

Vol. 9, No. 11, November, 2019, E-ISSN: 2222-6990 @ 2019 HRMARS

Journal of Business Ethics, 80(2), 225-235.

Davis, M. H. (1983a). Measuring individual differences in empathy: Evidence for a multidimensional approach. Journal of Personality and Social Psychology, 44(1), 113-126.

Davis, M. H. (1983b). The effects of dispositional empathy on emotional reactions and helping: A multidimensional approach. Journal of Personality, 51(2), 167-184.

Derry, R. (1989). An empirical study of moral reasoning among managers. Journal of Business Ethics, 8(11), 855-862.

Dietz, J., \& Kleinlogel, E. P. (2014). Wage Cuts and Managers' Empathy: How a Positive Emotion Can Contribute to Positive Organizational Ethics in Difficult Times. Journal of Business Ethics, 119(4), 461-472.

DiMaggio, P. J., \& Powell, W. W. (1983). The Iron Cage Revisited: Institutional Isomorphism and Collective Rationality in Organizational Fields. American Sociological Review, 48(2), 147. https://doi.org/10.2307/2095101

Donaldson, T., Preston, L. E., \& Preston, L. E. E. E. (1995). Theory the Stakeholder of the Concepts, Evidence , Corporation: and Implications. Management, 20(1), 65-91. https://doi.org/10.2307/258887

Duan, C., \& Hill, C. E. (1996). The Current State of Empathy Research. Journal of Counseling Psychology, 43(3), 261-274.

Duckworth, Holly Alison, Moore, R. A. (2010). Social Responsibility: Failure Mode Effects and Analysis.

Dumitriu, C., Timofti, I. C., Nechita, E., \& Dumitriu, G. (2014). The Influence of the Locus of Control and Decision-making Capacity upon the Leadership Style. Procedia - Social and Behavioral Sciences, 141, 494-499.

Eisenberg, N., \& Eggum, N. D. (2009). Empathic Responding: Sympathy and Personal Distress. In The Social Neuroscience of Empathy (pp. 71-84).

Ellen, P., Wiener, J. L. J., Cobb-Walgren, C., Scholder Ellen, P., Wiener, J. L. J., \& Cobb-Walgren, C. (1991). The role of perceived consumer effectiveness in motivating environmentally conscious behaviors. Journal of Public Policy \& Marketing, 10(2), 102-117. https://doi.org/10.2307/30000238

Fagbola, O. O., \& Popoola, S. O. (2015). Influence of Locus of Control, Work Motivation and Information Use on Decision- making of Managers in the Aviation Industry in Nigeria. Library Philosophy and Practice (e-Journal)., 1345.

Fernando, S., \& Lawrence, S. (2014). A Theoretical Framework for CSR Practices: Integrating Legitimacy Theory, Stakeholder Theory and Institutional Theory. Journal of Theoretical Accounting Research, 10(1), 149-178.

Feshbach, N. D. (1975). Empathy in Children: Some Theoretical and Empirical Considerations. The Counseling Psychologist, 5(2), 25-30.

Fishbein, M., \& Ajzen, I. (1975). Belief, Attitude, Intention, and Behavior, An Introduction to Theory and Research. Belief, Attitude, Intention, and Behavior, An Introduction to Theory and Research, (February), 578.

Ford, R. C., \& Richardson, W. D. (1994). Ethical decision making: A review of the empirical 
literature. Journal of Business Ethics. https://doi.org/10.1007/BF02074820

Frost, J. (2015). Regression Analysis : How Do I Interpret R - squared and Assess the Goodness of - Fit ? Regression Analysis. Retrieved from http://blog.minitab.com/blog/adventuresin-statistics-2/regression-analysis-how-do-i-interpret-r-squared-and-assess-thegoodness-of-fit

Gladstein, G. A. (1977). Empathy and Counseling Outcome: An Empirical and Conceptual Review. The Counseling Psychologist, 6(4), 70-79.

Gladstein, G. A. (1983). Understanding empathy: Integrating counseling, developmental, and social psychology perspectives. Journal of Counseling Psychology, 30(4), 467-482.

Gleichgerrcht, E., \& Young, L. (2013). Low levels of empathic concern predict utilitarian moral judgment. PLOS ONE, 8(4), 1-9.

Gupta, A., Briscoe, F., \& Hambrick, D. C. (2017). Red, blue, and purple firms: Organizational political ideology and corporate social responsibility. Strategic Management Journal, 38(5), 1018-1040. https://doi.org/10.1002/smj.2550

Hay, R., \& Gray, E. (1974). Social Responsibilities of Business Managers. Academy of Management Journal, 17(1), 135-143.

Hogan, R. (1969). Development of an empathy scale. Journal of Consulting and Clinical Psychology, 33(3), 307-316.

$\mathrm{Hu}$, Y. (2017). Neural and cognitive basis of third-party altruistic decision-making and its modulators. University of Bonn, 1-185.

Hughes, R. L., Ginnette, R. C., \& Curphy, G. J. (2012). LEADERSHIP: enhancing the lessons of experience. LEADERSHIP: enhancing the lessons of experience.

Ismail, M., Amat Johar, R., Mohd Rasdi, R., \& Alias, S. (2014). School as stakeholder of corporate social responsibility program: Teacher's perspective on outcome in school development. The Asia-Pacific Education Researcher, 23(2), 321-331.

Jiang, F., Zalan, T., Tse, H. H., \& Shen, J. (2018). Mapping the relationship among political ideology, CSR mindset, and CSR strategy: A contingency perspective applied to Chinese managers. Journal of Business Ethics, 147(2), 419-444.

Jolliffe, D., \& Farrington, D. P. (2006). Development and validation of the Basic Empathy Scale. Journal of Adolescence, 29(4), 589-611.

Jones, T. M., Wicks, A. C., \& Freeman, R. E. (2002). Stakeholder theory: The state of the art. The Blackwell Guide to Business Ethics, 17-37.

Julita, S., \& Wan Rafaei, A. (2009). Relationship of organisational commitment, locus of control and readiness to change among Nurses. Psycho-Behavioural Science and Quality of Life., 166-182.

Kemple, J. D. (2016). The Relationships Between Psychopathy, Empathy, and Everyday Moral Decision Making in an Undergraduate Sample. University Honors Program Theses, 210.

Kleinlogel, E. P., \& Dietz, J. (2014). Ethical decision making in organizations: The role of empathy. In K. Pavlovich \& K. Krahnke (Eds.), Organizing through empathy (Eds, pp. 115-129). UK: Routledge.

Koger, S. M., \& Winter, D. D. (2010). The psychology of environmental problems: psychology for 
sustainability. The psychology of environmental problems Psychology for sustainability 3rd ed.

Kohlberg, L. (1969). Stage and sequence: The cognitive developmental approach to socialization. In Handbook of Socialization: Theory and Research (pp. 347-480).

Levenson, H. (1972). Levenson Locus of Control Scales. Journal of Consulting and Clinical Psychology, 41(3), 397-404.

Liou, D., \& Bauer, K. D. (2007). Exploratory Investigation of Obesity Risk and Prevention in Chinese Americans. Journal of Nutrition Education and Behavior, 39(3), 134-141.

Loe, T. W., Ferrell, L., \& Mansfield, P. (2000). A Review of Empirical Studies Assessing Ethical Decision Making in Business. Journal of Business Ethics, 25(3), 185-204.

Manley, G. G., Benavidez, J., \& Dunn, K. (2007). Development of a personality biodata measure to predict ethical decision making. Journal of Managerial Psychology, 22(7), 664-682.

Mann, L., Radford, M., Burnett, P., Ford, S., Bond, M., Leung, K., ... Yang, K. S. (1998). Crosscultural differences in self-reported decision-making style and confidence. International Journal of Psychology, 33(5), 325-335.

Marano, V., \& Kostova, T. (2016). Unpacking the Institutional Complexity in Adoption of CSR Practices in Multinational Enterprises. Journal of Management Studies, 53(1), 28-54.

Martynov, A. (2009). Agents or stewards? Linking managerial behavior and moral development. Journal of Business Ethics, 90(2), 239-249.

Martynov, A., \& Logachev, S. (2016). Managerial Cognitive Moral Development and the F irm's Owners' Salience: Empirical Evidence. Administrative Issues Journal, 6(1), 73-87.

Mencl, J., \& May, D. R. (2009). The effects of proximity and empathy on ethical decision-making: An exploratory investigation. Journal of Business Ethics, 85(2), 201-226.

Midlarsky, E., \& Midlarsky, M. (1973). Some determinants of aiding under experimentallyinduced stress. Journal of Personality, 41(2), 305-327.

Orlitzky, M., \& Swanson, D. (2006). Socially responsible human resource management: Charting new territory. Ethics, 3-25.

Ornoy, H. (2010). Correlates of Employees' Attitudes Towards Participation in Decision Making. IUP Journal of Organizational Behavior, 9(1/2), 7-15. Retrieved from http://search.ebscohost.com/login.aspx?direct=true \&db=bth\&AN=49802879\&site=ehos t-live

Pierce, L., \& Snyder, J. A. (2015). Unethical Demand and Employee Turnover. Journal of Business Ethics, 131(4), 853-869.

PINTAR Foundation. (2014). PINTAR Foundation. Retrieved August 14, 2019, from PINTAR Foundation: https://www.mypintar.com.my/Overview-@-PINTAR_Foundation.aspx

Pollanen, R., Abdel-Maksoud, A., Elbanna, S., \& Mahama, H. (2017). Relationships between strategic performance measures, strategic decision-making, and organizational performance: empirical evidence from Canadian public organizations. Public Management Review, 19(5), 725-746. https://doi.org/10.1080/14719037.2016.1203013

Prel, D. J. B., Hommel, G., Rohrig, B., \& Blettner, M. (2009). Confidence interval or p-value? Deutsches Arzteblatt International, 106(19), 335-339. 
Qian, S. (2014). How do individual factors influence moral decision making in entrepreneurship? : the role of self-construal, temporal construal and moral identity. Electronic Theses and Dissertation, 1172.

Ramesh, K., Saha, R., Goswami, S., Sekar, \& Dahiya, R. (2019). Consumer's response to CSR activities: Mediating role of brand image and brand attitude. Corporate Social Responsibility and Environmental Management, 26(2), 377-387.

Rest, J. R. (1986). Moral development: Advances in research and theory. New York: Praeger.

Robbins, S. P. (2001). Organizational Behavior (9th ed.). New Jersey: Prentice-Hall.

Rotter, J. B. (1966). Generalized expectancies for internal versus external control of reinforcement. Psychological Monographs: General and Applied, 80(1), 1-28.

Rotter, J. B. (1990). Internal versus external control of reinforcement: A case history of a variable. American Psychologist, 45(4), 489-493.

Ruby, P., \& Decety, J. (2004). How Would You Feel versus How Do You Think She Would Feel? A Neuroimaging Study of Perspective-Taking with Social Emotions. Journal of Cognitive Neuroscience, 16(6), 988-999.

Rupp, D. E., Shao, R., Skarlicki, D. P., Paddock, E. L., Kim, T. Y., \& Nadisic, T. (2018). Corporate social responsibility and employee engagement: The moderating role of CSR-specific relative autonomy and individualism. Journal of Organizational Behavior, 39(5), 559-579.

Ryan, J. J. (2001). Moral reasoning as a determin ant of organizational citizenship behavior: A study in the public accounting profession. Journal of Business Ethics, 33, 233-244.

Schneider, S., Oppegaard, K., Zollo, M., \& Huy, Q. N. (2005). Socially Responsible Behaviour: Developing Virtue in Organizations. Faculty \& Research, 40, 2-54.

Scott, B. A., Colquitt, J. A., Paddock, E. L., \& Judge, T. A. (2010). A daily investigation of the role of manager empathy on employee well-being. Organizational Behavior and Human Decision Processes, 113(2), 127-140.

Shbail, A. M. O. (2018). A Theoretical Discussion of Factors Affecting the Internal Audit Quality in Jordanian Public Shareholding Companies, International Journal of Academic Research in Accounting, Finance and Management Sciences 8 (2): 218-227.

Smith, A., Hume, E. C., Zimmermann, R., \& Davis, A. (2007). The Global Significance Of Locus Of Control In Ethical Decision Making. Journal of College Teaching \& Learning, 4(2), 7-12.

Soderhamn, O., Bjornestad, J. O., Skisland, A., \& Cliffordson, C. (2011). Construct validity of the moral development scale for professionals (MDSP). Journal of Multidisciplinary Healthcare, 4, 165-170.

Solmu, S. T. (2004). [Working life, locus of control, and five-factor personality model]. Türk Psikoloji Bülteni, 10, 196-205.

Solomon, R. (1983). Ethics and Excellence. New York: Oxford University Press.

Stern, P. C. (2005). Understanding Individuals' Environmentally Significant Behavior. Environmental Law Reporter, 35, 10785-10790.

Stocks, E. L., Lishner, D. A., Waits, B. L., \& Downum, E. M. (2011). I'm Embarrassed for You: The Effect of Valuing and Perspective Taking on Empathic Embarrassment and Empathic Concern. Journal of Applied Social Psychology, 41(1), 1-26. 
INTERNATIONAL JOURNAL OF ACADEMIC RESEARCH IN BUSINESS AND SOCIAL SCIENCES

Vol. 9, No. 11, November, 2019, E-ISSN: 2222-6990 @ 2019 HRMARS

Swanson, D. L. (1999). Toward an integrative theory of business and society: A research strategy for corporate social performance. Academy of Management Review, 24(3), 506-521.

Thompson, T. S. (2000). The Impact of Locus of Control on Decision Making Styles of Mid-level Managers. Capella University.

Thompson, T. S. (2010). The impact of locus of control on decision making styles of midlevel managers. Capella University.

Tillman, C. J., Hood, A. C., Lawrence, E. R., \& Kacmar, K. M. (2015). When Birds of a Feather Flock Together: The Role of Core-Self Evaluations and Moral Intensity in the Relationship Between Network Unethicality and Unethical Choice. Ethics and Behavior, 25(6), 458481.

Trevino, L. K. (1986). Ethical Decision Making in Organizations: A Person-Situation Interactionist Model. Academy of Management Review, 11(3), 601-617.

Trevino, L. K., \& Youngblood, S. A. (1990). Bad apples in bad barrels: A causal analysis of ethical decision-making behavior. Journal of Applied Psychology, 75(4), 378-385.

Underwood, B., \& Moore, B. (1982). Perspective-taking and altruism. Psychological Bulletin, 91(1), 143-173.

Vashchenko, M. (2015). Decision- making for CSR: From a general notion to company-specific activities. Aarhus University.

Verbeke, A., \& Tung, V. (2013). The Future of Stakeholder Management Theory: A Temporal Perspective. Journal of Business Ethics, 112(3), 529-543. https://doi.org/10.1007/s10551012-1276-8

Verhaert, G. A., \& Poel, V. D. (2011). Empathy as added value in predicting donation behavior. Journal of Business Research, 64(12), 1288-1295.

Waal, D. F. B. M. (2008). Putting the Altruism Back into Altruism: The Evolution of Empathy. Annual Review of Psychology, 59(1), 279-300.

Walton, C. C. (1967). Corporate Social Responsibility. Belmont, CA: Wadsworth Publishing Company.

Weber, J. (1990). Managers' Moral Reasoning: Assessing Their Responses to Three Moral Dilemmas. Human Relations, 43(7), 687-702.

Wen, W., \& Song, J. (2017). Can returnee managers promote CSR performance? Evidence from China. Frontiers of Business Research in China, 11(1).

Westaby, J. D. (2005). Behavioral reasoning theory: Identifying new linkages underlying intentions and behavior. Organizational Behavior and Human Decision Processes, 98(2), 97-120.

Woltin, K. A., Corneille, O., Yzerbyt, V. Y., \& Forster, J. (2011). Narrowing down to open up for other people's concerns: Empathic concern can be enhanced by inducing detailed processing. Journal of Experimental Social Psychology, 47(2), 418-424.

Woon, L., Sambasivan, M., Jo, A., \& Siong, H. (2019). Corporate political activity and financial performance: A corporate social responsibility perspective. Asia-Pacific Contemporary Finance and Development, 26, 235-264.

Xu, H., Joyce, I., Aili, L., \& Yaping, G. (2010). Does participative leadership enhance work 
INTERNATIONAL JOURNAL OF ACADEMIC RESEARCH IN BUSINESS AND SOCIAL SCIENCES

Vol. 9, No. 11, November, 2019, E-ISSN: 2222-6990 @ 2019 HRMARS

performance by inducing empowerment or trust? The differential effects on managerial and non-managerial subordinates. Journal or Organizational Behavior, 31(1), 122-143.

Zhang, C. M., \& Greve, H. R. (2019). Dominant coalitions directing acquisitions: Different decision makers, different decisions. Academy of Management Journal, 62(1), 44-65. 